\title{
In Vitro Antibacterial Activity of Eurycoma Longifolia Jack (Tongkat Ali) Root Extract
}

\author{
Faisal GGa , Zakaria SMㄹ, Najmuldeen $\mathrm{GF}^{\mathrm{c}}$ \\ ${ }^{a}$ Department of Basic Medical Science, Kulliyyah of Dentistry, International Islamic University Malaysia, \\ ${ }^{b}$ Department of Biomedical Science, Kulliyyah of Allied Health Science, International Islamic \\ University Malaysia, \\ 'Faculty of Chemical and Natural Resources Engineering, University Malaysia Pahang, Malaysia.
}

\begin{abstract}
Introduction: Currently, researchers are aiming to explore herbal plants to replace synthetic drugs because herbal plants contain high active compounds and fewer side effects. Our study was done to determine the antibacterial activity of Eurycoma longifolia Jack (E. longifolia) root using ethanol based extract. Methods: Five types of pathogenic bacterial strains were used; Gram-positive (Staphylococcus aureus and Bacillus cereus) and Gram-negative (Escherichia coli, Salmonella typhi and Pseudomonas aeruginosa). Disc diffusion assay and Minimum Inhibitory Concentration (MIC) tests were used to determine the inhibition zone and turbidity of suspension which reflects the antibacterial activity of the extract. Results: The ethanolic extract of E. longifolia Jack root extract showed positive results against Gram-positive bacteria (S. aureus and B. cereus) and Gramnegative (S. typhi). B.cereus and S.typhi showed inhibition zone values of $11.76 \mathrm{~mm}$ and $14.33 \mathrm{~mm}$ at the extract concentration of $150 \mathrm{mg} / \mathrm{ml}$ that were higher than the positive control values $(9.00,12.67 \mathrm{~mm})$ respectively. However, E. coli and P. aeruginosa did not show any inhibition by the ethanol-based extract. Conclusion: From the results we can conclude that E.Longifolia root extract possesses antibacterial activity that can be further explored to produce new medicinal products.
\end{abstract}

KEYWORDS: Eurycoma longifolia Jack, antibacterial, root extract

\section{INTRODUCTION}

Exploring herbal plant is becoming an ultimate aim to cure health problems. ${ }^{1}$ Herbal and traditional medicines have already been used since thousands of years ago and showed improvement in health. Currently researchers are exploring the medicinal benefits of herbal plants because they contain high amounts of biologically active compounds and produce less side effects ${ }^{2}$ and also to overcome the emergence of multidrug bacterial resistance. ${ }^{3}$ Eurycoma longifolia Jack (E. longifolia) also known as Tongkat Ali, Bidara Pahit, Bba binh, and Hau phat (Vietnamese) can be found in Malaysia, Cambodia, Sumatra and Borneo. It belongs to family Simaroubacae and has a very bitter taste. E. longifolia Jack root is known to have many medical properties such as aphrodisiac, ${ }^{4,5}$ anticancer $^{6}$ and antimalarial. ${ }^{7}$

\section{Corresponding author:}

Asst. Prof. Dr. Ghasak Ghazi Faisal

Kulliyyah of Dentistry

Basic Medical Sciences Unit

Jalan Sultan Ahmad Shah

Indera Mahkota

Kuantan

Pahang, Malaysia

Telephone: +60105442293

Email:drghassak@yahoo.com
There is an increasing demand especially from pharmaceutical company to search for new medicine to treat diseases, while reducing side effects associated with synthetic drugs. Hence, plant-based medicine is a good choice as it contains a lot of secondary metabolites with the greatest effects on biological activities. ${ }^{8}$ According to Nadia et al. (2012), ${ }^{9}$ isolation of secondary metabolites from the root of $E$. longifolia Jack showed the presence of eurycomanone, eurycomanol, eurycomalactone, cathine-6-one alkaloid, phenolic components, tannins, quassionoids, and tripertenes. In this study, the main goal was to explore the antibacterial activity of $E$. longifolia Jack root using an ethanol based extraction method.

\section{MATERIALS AND METHODS}

Plant materials: The E. longifolia Jack root used in this study was purchased from a certified supplier. The sample was dried in the oven at $40^{\circ} \mathrm{C}$ until constant weight was achieved. After that, the dried plant materials were grinded into powder using a dry grinder and $35.7404 \mathrm{~g}$ was obtained. The active compounds of the sample were extracted with absolute ethanol around its boiling point at 60 to 65 ${ }^{\circ} \mathrm{C}$ using Soxhlet extraction method. It was done for approximately 24 hours. Then, the extracts were dried under vacuum and reduced pressure using rotary evaporator at $60^{\circ} \mathrm{C}$ and at a pressure of $175 \mathrm{mbar}$. This was done to evaporate the solvents and to obtain the crude extracts. The weight of final extract was 11.8 $\mathrm{g}$ and the percentage yield of ethanol extract of $E$. 
longifolia Jack was 33\%. The residue obtained were placed in universal bottle and stored in freezer at $-4^{\circ} \mathrm{C}$ until further test was conducted. Finally, the crude extracts of root $E$. longifolia Jack materials were used in the antibacterial assay. The working stocks for the crude extract of root of E. longifolia Jack were prepared at $50 \mathrm{mg} / \mathrm{ml}, 100 \mathrm{mg} / \mathrm{ml}$ and $150 \mathrm{mg} /$ $\mathrm{ml}$ by dissolving $100 \mathrm{mg}, 200 \mathrm{mg}$ and $300 \mathrm{mg}$ of the crude extracts into $2 \mathrm{ml}$ of $25 \%$ ethanol respectively. Erythromycin and Ciprofloxacin containing discs were used as positive controls for treatment of Grampositive and Gram-negative bacteria respectively.

Bacterial strains: Reference strains of human pathogens were used, including Gram-positive bacteria, Bacillus cureus (ATCC 25923) and Staphylococcus aureus (ATCC 14778), while Gramnegative bacterial strains were Pseudomonas aeruginosa (ATCC 27853), Escherichia coli (ATCC 25922), and Salmonella thypi (from Institute of Medical Research Health Ministry, IMR). For the antibacterial assay, the bacteria were grown on the Muller Hinton (MH) broth and agar and put in the incubator at $37^{\circ} \mathrm{C}$ and observed the turbidity.

\section{Adjustment of Microorganism Number and Inoculums Preparation: Direct Colony} suspension method was used to prepare inoculation suspension. ${ }^{10,11}$ Barium Sulfate $(0.5$ McFarland) of standard suspension was prepared by adding 0.5 part of $0.048 \mathrm{M} \mathrm{BaCl}_{2}$ to 99.5 parts of $0.18 \mathrm{M} \mathrm{H}_{2} \mathrm{SO}_{4}$ and agitated vigorously until a homogenous suspension was obtained. The turbidity of the suspension was verified by measuring the optical density at $600 \mathrm{~nm}\left(\mathrm{OD}_{600}\right)$ by the spectrophotometer. Proper dilutions were done to get an absorbance value of $0.008-0.10$ which corresponded to 0.5 McFarland standards. Under aseptic condition, five colonies isolated by ignition-sterilized inoculation loop from 24 hour cultivated agar plates of each microbe were suspended separately in $20 \mathrm{ml}$ pre-warmed $(370 \mathrm{C})$ broth medium (Nutrient broth (NB) for bacterial strains and kept in screw-cap bottles and incubated at $37^{\circ} \mathrm{C}$. During the incubation period, aliquots of $1 \mathrm{ml}$ were taken from the culture at hourly intervals and optical density $\left(\mathrm{OD}_{600}\right.$ for bacterial suspension) were measured using spectro-

\section{RESULTS}

Table I. Antibacterial activity profile of ethanol extract of Eurycoma longifolia Jack root using disc diffusion method photometer. Finally, the resultant broth suspensions contained $10^{7} \mathrm{CFU} / \mathrm{ml}$ for bacterial spp. was used for all experiments performed. Suspensions were always agitated thoroughly before OD measurement and inoculation.

Agar Disc Diffusion Assay: The Kirby-Bauer Disc Diffusion method was chosen to determine the anticipated antimicrobial activity of $E$. Longifolia Jack root. ${ }^{11}$ Five pathogenic bacterial strains were swabbed into the $\mathrm{MH}$ agar to grow the bacteria for a night in the incubator at $37^{\circ} \mathrm{C}$. The filter paper discs loaded with crude extract of $E$. longifolia Jack root and reference antibiotic-containing disc (5 $\mu \mathrm{g} / \mathrm{disc}$ ciprofloxacin and $5 \mu \mathrm{g} /$ disc erythromycin) were laid down on the inoculated agar plates using sterile forceps with gentle pressing to ensure a good adherence to the agar surface. The discs were distributed to be at least $15 \mathrm{~mm}$ from the edge of the plate and no closer than $24 \mathrm{~mm}$ from center to center. Finally, theplateswereinvertedupsidedownward and incubated at $37^{\circ} \mathrm{C}$ for 24 hour. After the incubation period, the zone of inhibition $(\mathrm{mm})$ around each disc was measured using ruler and compared with reference antibiotics used.

Broth Microdilution test (MIC): Microdilution method $^{12}$ was used in this study to identify the inhibition growth of test organisms through the minimal concentration of root extract. Serial double-fold dilutions were carried out in sterile 96-well plate. First, all wells to use were filled with $180 \mu$ l of MullerHinton broth containing microorganisms. Then, $20 \mu \mathrm{l}$ of sample extract were transferred to the first well and mixed. Three fold serial-dilution was performed by transferring $100 \mu \mathrm{l}$ of the mixture in the first well into the next consecutive wells, until the end of the row. The last well, $100 \mu \mathrm{l}$ of the mixture were discharged, so the total volume of each well was 100 $\mu \mathrm{l}$. The microplate was incubated at $37^{\circ} \mathrm{C}$ for $18-24$ hours. The MIC value was determined by comparing the turbidity of the mixture in test wells with blank wells. To decrease the occurrence of bias, the test was assessed by two examiners who were blinded to the type of mixture. The test of all sample and control were performed in triplicates.

Zone of inhibition $(\mathrm{mm})($ Mean \pm SD)

\begin{tabular}{|c|c|c|c|c|c|c|}
\hline \multicolumn{3}{|c|}{ Extract concentration } & & \multicolumn{2}{|c|}{ Positive Control } & \multirow{2}{*}{$\begin{array}{c}\text { Negative Control } \\
25 \% \text { Ethanol }\end{array}$} \\
\hline Bacteria & $50 \mathrm{mg} / \mathrm{ml}$ & $100 \mathrm{mg} / \mathrm{ml}$ & $150 \mathrm{mg} / \mathrm{ml}$ & Erythromycin & Ciprofloxacinc & \\
\hline S. aureus & $5.67 \pm 2.05$ & $8.78 \pm 1.13$ & $10.67 \pm 0.82$ & $11.78 \pm 0.79$ & - & \\
\hline B. cereus & $5.89 \pm 1.80$ & $9.44 \pm 1.42$ & $11.67 \pm 1.50$ & $9.00 \pm 1.05$ & - & \\
\hline S. typhi & $8.44 \pm 0.50$ & $9.33 \pm 0.82$ & $14.33 \pm 0.47$ & - & $12.67 \pm 3.13$ & - \\
\hline E. coli & - & - & & & $8.39 \pm 0.42$ & - \\
\hline P.aeruginosa & - & - & & & $12.28 \pm 0.47$ & - \\
\hline
\end{tabular}


According to the results in Table I, we have found that the root extract possess antibacterial activity against Staphylococcus aureus, Bacillus cereus and Salmonella typhi which was demonstrated by a zone of inhibition of growth which increased with the increase in the concentration of the extract. However no antibacterial activity was detected against Escherichia coli and Pseudomonas aeruginosa.

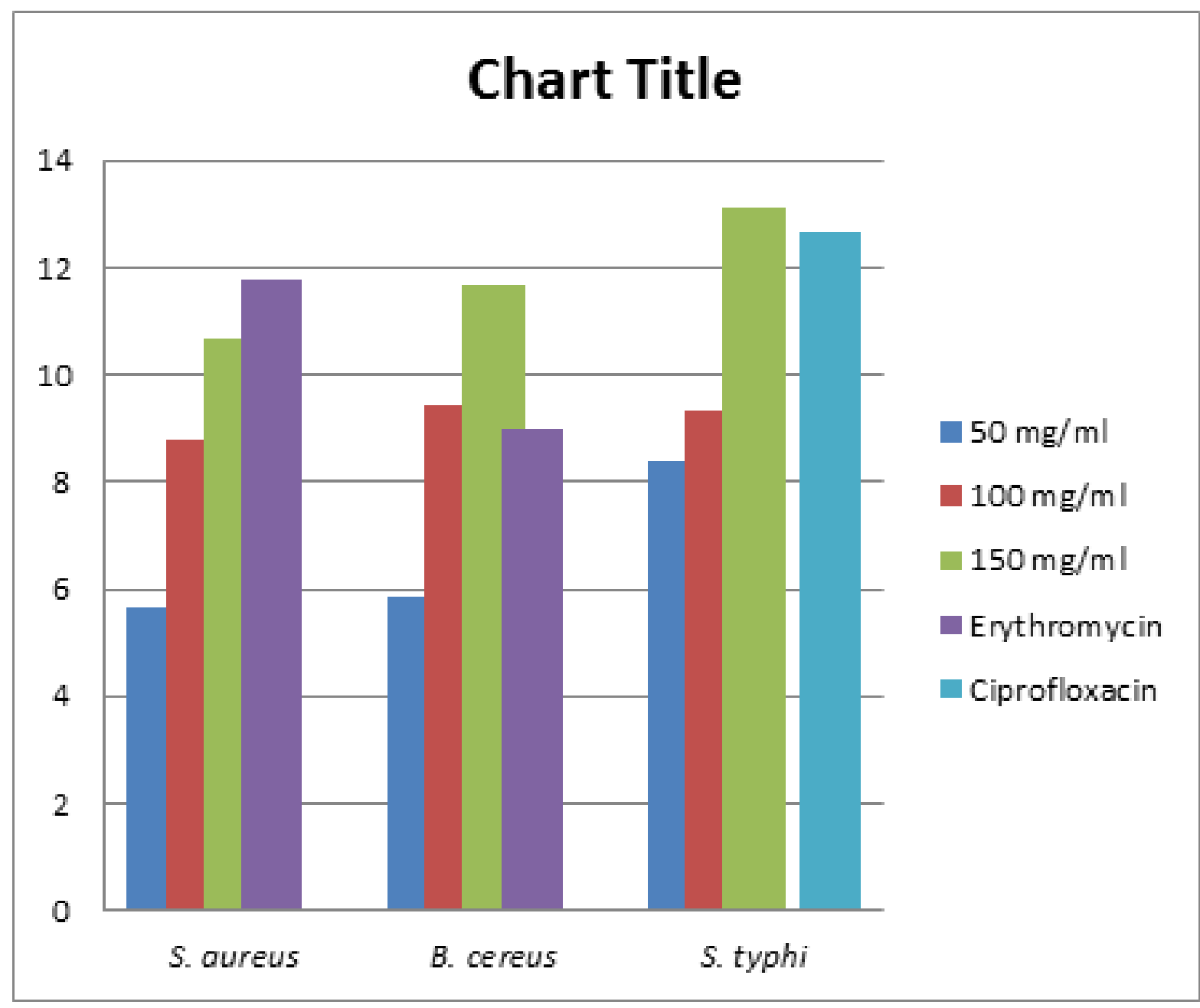

Figure 1: Diameter of inhibition zone $(\mathrm{mm})$ against human pathogenic bacteria using different concentrations of E.L root extract compared to positive control (Erythromycin and ciprofloxacin).

Figure 1 shows that the highest inhibition zone is achieved with the highest concentration of extract $150 \mathrm{mg} /$ $\mathrm{ml}$. The inhibition zones for B.cereus and S.typhi at extract concentration of $150 \mathrm{mg} / \mathrm{ml}$ are higher than that of the positive control.

Table II. Minimum inhibitory concentration (MIC) of E.L root extract on pathogenic bacteria

\begin{tabular}{lll}
\hline $\begin{array}{l}\text { Concentration of plant } \\
\text { extract }(\mathrm{mg} / \mathrm{ml})\end{array}$ & $\begin{array}{l}\text { StaphylococcusBacillus cereus } \\
\text { aureus }\end{array}$ & Salmonella typhimirium \\
\hline
\end{tabular}

\begin{tabular}{llll}
\hline 200 & + & + & + \\
100 & + & + & + \\
50 & + & + & + \\
25 & + & + & + \\
12.5 & - & + & - \\
6.25 & - & - & - \\
3.125 & - & - & - \\
1.560 & - & - & \\
\hline
\end{tabular}

$+=$ clear

- = turbid 


\section{DISCUSSION}

Our study showed positive results as there were inhibition zones of bacterial growth. Ethanol extracts of E. longifolia Jack root displayed antibacterial activity against pathogenic Gram+ve and some Gram -ve bacteria. Our results are new in documenting antibacterial activity of the root extract using alcohol and heat mediated extraction. Previous research on the antibacterial properties of E.longifolia is limited to a few studies that have different results some of which are contradictory to others. The study by Farouk et al. ${ }^{13}$ showed that the leaves and stems of Eurycoma longifolia possess antibacterial activity while the roots did not show any activity. Another study by Farouk et al..$^{14}$ also indicated that only the leaves part of $E$. longifolia Jack shows the antibacterial activity. Only one study which was done by Danial et al. ${ }^{15}$ reported that there was inhibition of the growth of pathogenic bacteria by E.longifolia Jack root extract and that study used a different extraction method. On the contrary, Tzar et al. ${ }^{16}$ stated that there was no antibacterial activity of $E$. longifolia root extract. This concludes that many factors contribute for plants to show its therapeutic properties, for example the mode of processing of samples to obtain the crude extract and the right handling before, after and during the experiment was conducted.

In our study we used ethanol extraction method. In general, alcoholic extracts displayed higher antibacterial and antifungal activity than aqueous extract. ${ }^{17}$ Our method of extraction and solvent used were different from the previous mentioned studies, which might be the reason behind the different results that we obtained. We chose Soxhlet method as our method of extraction because it produces higher crude extract yield when compared to other methods. ${ }^{18}$ Besides, it also reduces the usage of solvent and produces high purity product. Moreover, the hot continuous extraction can release more secondary metabolites, especially flavonoids, eurycomanone, eurycomanol, eurycomalactone, quanissoids, and triterpenes. ${ }^{19}$

Staphylococcus aureus is a gram positive bacteria which causes a range of diseases from minor skin infections, such as folliculitis, scalded skin syndrome, and life threatening disease like pneumonia, meningitis, food poisoning and sepsis. ${ }^{20}$ The inhibition zones value for $S$. aureus recorded for ethanol root extract for three concentrations were $5.67 \pm 2.05 \mathrm{~mm}(50 \mathrm{mg} / \mathrm{ml}), 8.78 \pm 1.13 \mathrm{~mm}(100$ $\mathrm{mg} / \mathrm{ml})$ and $10.78 \pm 0.79 \mathrm{~mm}(150 \mathrm{mg} / \mathrm{ml})$ Table I. However, all inhibition zone values recorded was lower than positive control values (erythromycin) (Figure 1).

Bacillus cereus is a pathogenic bacteria that can cause diarrhoea, gangrene and ocular infection. ${ }^{21}$ $B$. cereus inhibition zone recorded for ethanol root extract for three concentrations were $5.89 \pm 1.80 \mathrm{~mm}$ $(50 \mathrm{mg} / \mathrm{ml}), 9.44 \pm 1.42 \mathrm{~mm}(100 \mathrm{mg} / \mathrm{ml})$, and 11.67 $\pm 1.50 \mathrm{~mm}(150 \mathrm{mg} / \mathrm{ml})$ (Table I). The inhibition zone value at $150 \mathrm{mg} / \mathrm{ml}$ was higher than positive control values (erythromycin) which means that the extract has a strong antibacterial effect against this bacteria (Figure 1).

The incidence of antibacterial resistant bacteria causing food borne infection, like S. typhi has remarkably increased and lead to death. ${ }^{22}$ In addition, the contamination of fresh fruits and vegetables has increased the incidence of food-borne outbreaks..$^{23} \mathrm{~S}$. typhi was the only gram-negative bacteria that showed inhibition of growth by the ethanol root extract. Besides, compared to other bacteria's inhibition zones, S. typhi showed the highest inhibition zone values which were $8.44 \pm 0.50 \mathrm{~mm}(50 \mathrm{mg} / \mathrm{ml}), 9.33$ $\pm 0.82 \mathrm{~mm}(100 \mathrm{mg} / \mathrm{ml})$ and $14.33 \pm 0.47 \mathrm{~mm}(150$ $\mathrm{mg} / \mathrm{ml}$ ) (Table 1). The inhibition zone value at 150 $\mathrm{mg} / \mathrm{ml}$ was higher than the positive control values (ciprofloxacin). At $150 \mathrm{mg} / \mathrm{ml}$ extract concentration, we found that $B$. cereus and S. typhi had higher inhibition zones compared to the positive control values (Figure 1).

Regarding other gram negative bacteria, no inhibition zone was recorded for $E$. coli and $P$. aeruginosa (Table I). This may be due to the fact that gram-negative bacteria has an inner layer and outer layer containing thick lipid bilayers that lead to its selective permeability ${ }^{24}$ and make it more resistant.

In order to measure the strength of the exact inhibitory concentration, minimal inhibitory concentration testing (MIC) was performed according to positive results in the disc diffusion assay. The minimal inhibitory concentration was identified by the clearness of the turbidity of the well. The identification was done by comparing the test well to the control well by observing with naked eyes in sufficient light source. The procedure was conducted by two examiners who were blinded for the type of mixture being examined to reduce bias. From the result, the clear well was chosen until the lowest concentration and was recorded.

According to the MIC of E. longifolia Jack root against gram-positive and gram-negative pathogenic bacteria (Table II), it inhibited the visible growth of S. aureus, B. cereus and S. typhi from descending concentrations of $200-12.5 \mathrm{mg} / \mathrm{ml}$ where the mixture of bacterial culture and the extract produced clear solutions. The lowest MIC value of the extract was detected against gram-positive bacteria which was Bacillus cereus at a value of $12.5 \mathrm{mg} / \mathrm{ml}$. All solutions became turbid or cloudy at the concentration of $12.5-6.25 \mathrm{mg} / \mathrm{ml}$. Thus, the lowest MIC of the extract that inhibited the growth of all three pathogenic bacterial strains was 25 $\mathrm{mg} / \mathrm{ml}$.

\section{CONCLUSION}

Our study showed that ethanol-based Eurycoma longifolia Jack root extract has antibacterial properties on the following pathogenic strains: 
S.aureus, B. cereus, and S. typhi. Thus, the results from this study have revealed the potential antimicrobial activity of E.longifolia. Further studies on isolating bioactive compounds using bioassay guided approach are recommended to ensure the active compounds presence from $E$. longifolia Jack. There are many aspects that influence the antibacterial activities such as part of plant, methods of extraction and types of solvents used to get the crude extract.

\section{REFERENCES}

1. Dubey NK, Kumar R, and Tripathi P. Global promotion of herbal medicine: India's opportunity. Current Science-Bangalore 2004; 86:37-41.

2. Verma $S$ and Singh SP. Current and future status of herbal medicines. Vet World. 2008; 1:347-50

3. Spellberg B, Guidos R, Gilbert D, Bradley J, Boucher HW, Scheld WM, Edwards J. The epidemic of antibiotic-resistant infections: a call to action for the medical community from the Infectious Diseases Society of America. Clin Infect Dis 2008; 46:155-64.

4. Wiart C. Medicinal Plants Of The Asia-Pacific: Drugs for the future? World Scientific Publishing Co. Pte. Ltd. 2006; 1:394-6.

5. Ang HH. Ngai TH \& Tan TH. Effects of Eurycoma longifolia Jack on sexual qualities in middle aged male rats. Phytomedicine 2003; 10:590-3.

6. Bhat R, and Karim AA. Tongkat Ali (Eury coma longifolia Jack): A review on its ethno botany and pharmacological importance. Fitote rapia 2010; 81:669-79.

7. Chan KL, Choo CY, Abdullah NR, \& Ismail Z. Antiplasmodial studies of Eurycoma longifolia Jack using the lactate dehydrogenase assay of Plasmodium falciparum. J Ethnopharmacol 2004; 2:223-7.

8. Iwu MW, Duncan AR. \& Okunji CO. New antimicrobials of plant origin. Perspectives on new crops and new uses. ASHS Press, Alexandria, VA. 1999; 457-62.

9. Mohd Effendy N, Mohamed N, Muhammad N, Naina Mohamad I \& Shuid AN. Eurycoma longifolia: medicinal plant in the prevention and treatment of male osteoporosis due to androgen deficiency. Evid Based Complement Alternat Med 2012; Article ID 125761,9 pages.

10. Coyle MB. Manual of antimicrobial susceptibility testing. American Society for Microbiology 2005.

11. Goldman E, \& Green LH. Practical handbook of microbiology. CRC Press 2008.

12. Serrano MC, Ramírez M, Morilla D, Valverde A, Chávez $M$ et al. A comparative study of the disc diffusion method with the broth microdilution and Etest methods for voriconazole susceptibility testing of Aspergillus spp. J Antimicrob Chemother 2004; 53:739-42.

13. Farouk $A \&$ Benafri A. Antibacterial activity of Eurycoma Longifolia Jack. A Malaysia Medicinal Plant. Saudi Med J 2007; 28:1422-4.
14. Farouk AE, Nawi MN \& Hassan S. Antibacterial peptides from Eurycoma longifolia (Tongkat Ali) and Labisia pumila (Kacip Fatimah) leaves in Malaysia. Sci Brun 2008; 9:55-63.

15. Danial M, Saghal G, Mubbarakh SA \& Sundarasekar J. Antibacterial studies on in vivo plant parts of medicinally important Eurycoma longifolia (Tongkat Ali). Pak J Bot 2013; 45:1693-700.

16. Tzar M, Hamidah Y, Hartini M, Marianayati M \& Nazrun A. The Antibacterial or Antifungal Effects of Eurycoma longifolia Root Extract. The Internet Journal of Herbal and Plant Medicine 2011; 1.

17. Johnson DB, Shringi BN, Patidar DK, Chalichem NSS \& Javvadi AK. Screening of Antimicrobial Activity of Alcoholic \& Aqueous Extract of Some Indigenous Plants. Indo Global J Pharm Sci 2011; 1:186-93.

18. Ong E.S. Extraction methods and chemical standardization of botanicals and herbal preparations. J of Chromatogr B 2004; 812:2333.

19. United Nations Industrial Development Organization, Handa SS, Khanuja SPS, Longo G, \& Rakesh DD. Extraction Technologies for Medicinal and Aromatic Plants. Earth, Environment and Marine Sciences and Technologies 2008.

20. Jamil M, Andleeb S, \& Ali S. Antibacterial Activity of antibiotics against pathogens and their genomic DNA Isolation. Punjab Univ. J. Zool 2009; 24:87-96.

21. Bottone EJ. Bacillus cereus, a volatile human pathogen. Clin Microb Rev 2010; 23:382-98.

22. Moges F, Endris M, Mulu A, Tessema B, Belyhun $Y$, Shiferaw $Y$, Kassu $A$. The growing challenges of antibacterial drug resistance in Ethiopia. J Glob Antimicrob Resist 2014; 2:148-54.

23. Pui CF, Wong WC, Chai LC, Tunung R, Ponniah et al. Salmonella : A foodborne pathogen. Int Food Res J 2011; 18:465-73.

24. Brooks GF, Carroll KC, Butel JS, Morse SA \& Mietzner T. Jawetz, Melnick, \& Adelberg's Medical Microbiology (25th edn.) United State of America. McGrawHill Companies, Inc. 2006. 